\title{
PELATIHAN MS. OFFICE WORD DAN EXCEL BAGI PERANGKAT DESA \& MASYARAKAT DESA CIARUTEUN ILIR BOGOR
}

\author{
Max Teja Ajie C. W. ${ }^{1}$, Efy Yosrita ${ }^{2}$, Darma Rusjdi ${ }^{3}$, Meilia Nur Indah S. ${ }^{4}$, \\ Indrianto $^{5}$, Rizqia Cahyaningtyas ${ }^{6}$, Dewi Arianti W. ${ }^{7}$, Herman Bedi A. ${ }^{8}$ \\ ${ }_{1,2,3,4,5,6,7,8}$ Sekolah Tinggi Teknik - PLN \\ Departemen Teknik Informatika \\ Email $^{1}:$ max@sttpln.ac.id
}

\begin{abstract}
Abstrak
Desa Ciaruteun Ilir berada di Kecamatan Cibungbulang, Kabupaten Bogor. Terletak sekitar $25 \mathrm{~km}$ dari ibukota kabupaten. Populasi rata-rata, sebagian besar pertanian, berada di garis kemiskinan dan memiliki tingkat pendidikan rendah. Fasilitas pendidikan formal masih sangat terbatas. Oleh karena itu, pelatihan dan kursus dari pemerintah dan pihak lain diperlukan untuk meningkatkan keterampilan dan meningkatkan pengetahuan penduduk. Kursus keterampilan diharapkan dapat meningkatkan pendapatan masyarakat. Sementara wawasan luas diharapkan dapat meningkatkan kesadaran warga akan pentingnya pendidikan. Tim PKM ini bermaksud memberikan pelatihan terkait Teknologi Informasi kepada masyarakat, terutama perangkat desa setempat, yaitu dalam hal ini pengenalan Microsoft Office. Komunitas akan diperkenalkan ke MS. Office Word dan Excel, di mana Word memungkinkan dokumentasi dan administrasi penduduk desa sementara Excel digunakan dalam transaksi jual beli dan dapat memproses dan merekapitulasi hasil pertanian. Dengan aplikasi ini dari Microsoft Office akan membuka kesempatan bagi warga untuk menambah pengetahuan dan belajar menggunakan teknologi informasi untuk memajukan ekonomi dan produk pertanian di sana serta untuk aparat desa dalam rangka mengoptimalkan administrasi desa. Dengan pelatihan Microsoft Office Word dan Excel, warga desa akan dilengkapi dengan kemampuan untuk dapat mengolah data dan informasi tentang produk-produk sawah atau kebun mereka dan terutama untuk perangkat desa dalam sistem administrasi desa.
\end{abstract}

Kata kunci: Pelatihan Microsoft Office, Word, Excel, PKM, teknologi informasi

\begin{abstract}
Ciaruteun Ilir Village is in the Cibungbulang District, Bogor Regency. It is located approximately $25 \mathrm{~km}$ from the district capital. The average population, mostly farming, is on the poverty line and has a low level of education. Formal education facilities are still very limited. Therefore, training and courses from the government and other parties are needed to increase skills and improve the
\end{abstract}


knowledge of the population. Skills courses are expected to increase people's income. While broad insight is expected to increase citizens' awareness of the importance of education. This PKM team intends to provide training related to Information Technology to the community, especially local village equipment, namely in this case the introduction of Microsoft Office. The community will be introduced to MS. Office Word and Excel, where Word allows the documentation and administration of villagers while Excel is used in buying and selling transactions and can process and recapitulate agricultural produce. With this application from Microsoft Office will open the opportunity for citizens to increase knowledge and learn to use information technology to advance the economy and agricultural products there as well as for village officials in order to optimize village administration. With the training of Microsoft Office Word and Excel, villagers will be equipped with the ability to be able to process data and information on the products of their rice fields or gardens and especially for the village apparatus in the village administration system.

Keywords: Training Microsoft Office, Word, Excel, PKM, information technology

\section{PENDAHULUAN}

Desa Ciaruteun Ilir, Kecamatan Cibungbulang, merupakan salah satu desa di Kabupaten Bogor, Jawa Barat. Desa Ciaruteun Ilir dengan kepadatan penduduk sebesar 29 per km ini memiliki jumlah penduduk sebesar 10.259 jiwa. Jumlah laki-laki di desa ini adalah 5.232 jiwa dan perempuan 5.027 jiwa dengan jumlah kepala keluarga sebesar 2.705 KK. Mayoritas masyarakat memiliki tingkat pendidikan terakhir Sekolah Menengah Pertama (SMP) . Jumlah penduduk yang berada pada usia 21-38 tahun menempati urutan terbanyak yaitu sebesar 996 untuk penduduk laki-laki dan 796 untuk penduduk perempuan. Pertanian merupakan sumber mata pencaharian utama di Desa Ciaruteun Ilir, terlihat dari besarnya luas lahan yang digunakan sebagai persawahan. Mayoritas penduduk di desa ini bermata pencaharian sebagai petani, baik sebagai petani pemilik lahan maupun sebagai buruh tani. Jumlah penduduk yang bekerja sebagai buruh tani menempati jumlah yang jauh lebih besar daripada penduduk yang bekerja sebagai petani pemilik lahan (BPS).

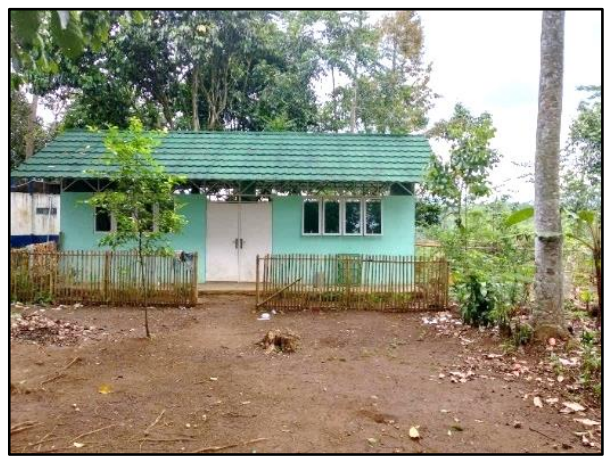

Gambar 1. Rumah Komunitas Belajar di Kampung Poncol, Ciaruteun Ilir 
Pada beberapa bagian Desa Ciaruteun Ilir, misalnya di Kampung Poncol, banyak warga desa belum mengenyam bangku sekolah karena tekendala minimnya fasilitas pendidikan, mahalnya biaya sekolah dan jarak ke sekolah yang cukup jauh. Banyak orang tua yang menyuruh anaknya untuk membantu di ladang dibandingkan duduk di bangku sekolah. Di kampung tersebut, terdapat komunitas belajar yang dibentuk oleh sekelompok masyarakat. Tetapi komunitas belajar tersebut tidak memiliki fasilitas yang memadai dan tenaga pengajar yang cukup. Tempat belajar komunitas tersebut ditunjukkan pada gambar 1. Tenaga pengajar hanya berasal dari relawan ataupun masyarakat sekitar yang jumlahnya masih sangat kurang jika dibandingkan dengan jumlah anak dengan rentang umur 6-12 tahun yang sangat membutuhkan pendidikan.

Perkembangan teknologi dari waktu ke waktu semakin pesat. Perkembangan tersebut tidak hanya pada tatanan elite-elite tertentu akan tetapi sampai pada tatanan lokal. Hal tersebut terlihat dari pola hidup masyarakat lokal yang serba teknologi. Bahkan teknologi tidak lagi dipandang sebagai kebutuhan tersier akan tetapi sudah menjadi kebutuhan primer dalam era global dan serba modern ini. Baik teknologi komunikasi, komputasi, pelaratan rumah tangga, dan lain sebagainya.

Perkembangan teknologi harusnya selaras dengan perkembangan sumber daya manusia sebagai pengguna teknologi. Sehingga tujuan daripada teknologi yakni sebagai alat untuk membantu meringankan pekerjaan manusia dapat tercapai. Namuan realita yang terjadi di Indonesia brainware (penggunanya) belum siap secara keseluruhan dalam menerima perkembangan teknologi yang sangat pesat. Akibatnya perkembangan teknologi disebagian tempat di Indonesia khususnya desa Ciaruteun Ilir menjadi tidak tepat guna. Secara data survei PT. Telkom desa Ciaruteun Ilir 70\% masyarakat Sumenep mengalami buta IT (PT. Telkom, Survei Melek IT, 2013). Yang menjadi sangat miris buta IT ini tidak hanya disandang oleh masyarakat biasa namun jajaran pemerintah lapisan bawahpun (aparatur desa) mengidap buta IT. Padahal dengan adanya UU no 6 tahun 2014 tentang Desa, menuntut aparatur desa untuk paham dengan pengelolaan manajerial secara IT untuk memperoleh hasil pengelolaan yang valid dan lebih professional.

Desa Ciaruteun Ilir memiliki masyarakat buta IT sangat tinggi bahkan pada jajaran pemerintah desanya hampir dapat dikatakan 90\% mengalami buta IT. Padahal jika dilihat dari pola manajemen desa, banyak hal yang harus dikelola dengan bantuan IT untuk efektivitas dan efisiensi waktunya. Misal pengelolaan anggaran desa, pengelolaan administrasi, akuntablelity, presentasi hingga pelaporan yang membutuhkan software IT. Banyak software yang tersedia untuk mengelola hal-hal tersebut salah satunya Microsoft Office. Akan tetapi permasalahan sentralnya kembali lagi terhadap sumber daya penggunanya yang kurang mumpuni. Maka program ini tim penulis memfokuskan pada program pengabdian masyarakat untuk memberikan pelatihan Microsoft Office pada aparatur desa ditiap-tiap kecamatan. Besar harapan tim penulis program ini dapat dilaksanakan secara merata se-desa Ciaruteun Ilir, namun dngan adanya beberapa kendala 
salah satunya tenaga maka program ini akan dilakukan secara bertahap. Namun pada program PKM-M ini memilih suatu kecamatan yang dinilai sangat tinggi tingkat buta IT pada aparatur desanya. Kecamatan yang dipilih yaitu Desa Ciaruteun Ilir, Kecamatan Cibungbulang dengan tingkat buta IT aparatur desanya mencapai $90 \%$

Microsoft Office merupakan software yang harus dikuasai oleh perangkat desa, namun tidak semua perangkat desa menguasainya. Hal tersebut disebabkan belum adanya pelatihan yang baik dan kurangnya didukung pengaplikasian teknologi informasi di masa sekarang ini. Perangkat Desa Patemon sendiri masih kurang baik dalam penggunaan Microsoft Office, sehingga pelayanan kepada masyarakat cenderung dan untuk membuat laporan atau surat menyurat memerlukan waktu yang lama. Oleh karena itu, Pelatihan Microsoft Office perlu diberlakukan.

Tujuan dari Program pelatihan adalah untuk meningkatkan kemampuan Perangkat Desa dalam meliputi mengolah dan mengedit berkas-berkas penting yang berkaitan dengan kelengkapan surat-menyurat, surat keterangan maupun keamanan dari arsip-arsip penting itu sendiri.Manfaat yang di dapat dari Program ini adalah kemudahan dalam kearsipan sehingga mampu melayani masyarakat secara lebih cepat dan tepat.

Berdasarkan latar belakang tersebut, Tim PKM STT PLN bermaksud mengadakan kegiatan pengenalan dan pelatihan Microsoft Office Word dan Excel bagi tenaga pengajar komunitas belajar Kampung Poncol dan warga Desa Ciaruteun Ilir. Dengan pelatihan tersebut, warga diharapkan memiliki tambahan modal ketrampilan untuk lebih meningkatkan taraf hidup warga.

\section{METODE}

Metode pelaksanaan yang digunakan untuk melaksanakan kegiatan Program Kemitraan Masyarakat (PKM) tahun 2017/2018 Semester Genap ini adalah : 


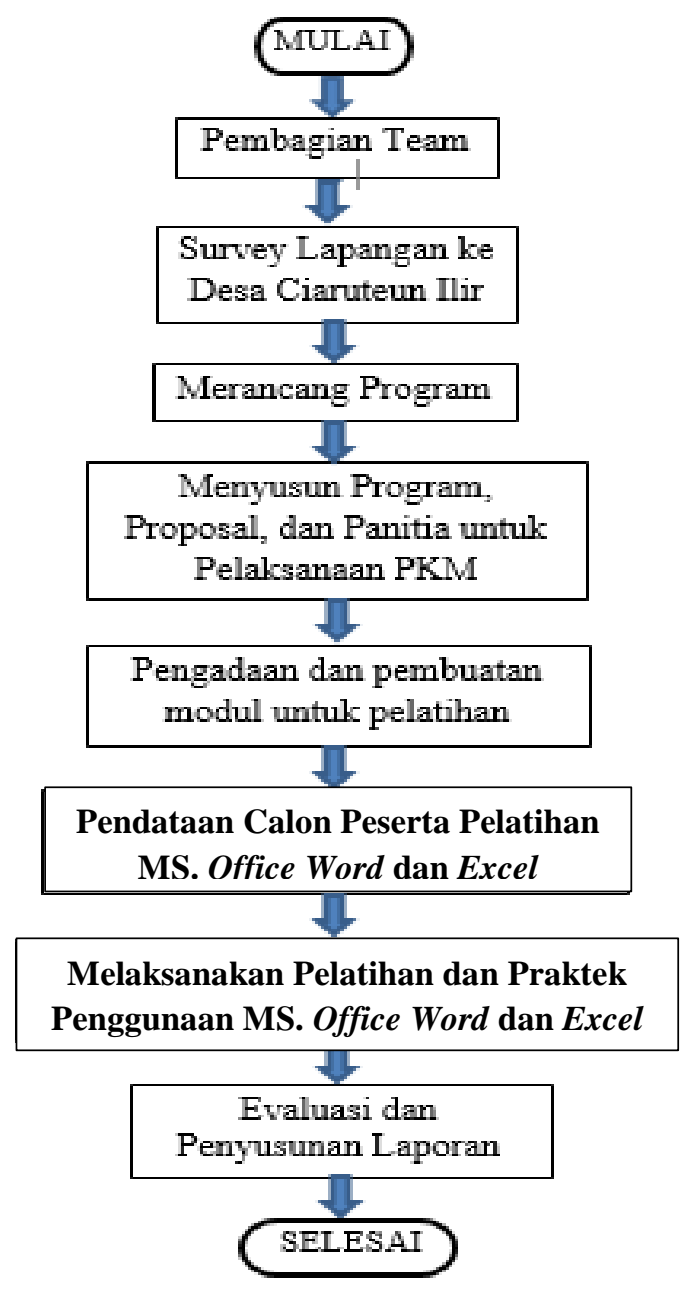

Gambar 2. Tahapan Pelaksanaan Kegiatan PKM

\subsection{Sifat dan Bentuk Kegiatan}

Pelaksanaan PELATIHAN MS. Word dan MS. Excel dan Pengenalan Microsoft Office ini akan dilaksanakan dalam 2 sesi dengan target jumlah peserta adalah 30 orang. Kegiatan ini dapat diselenggarakan dalam 3 hari kerja. Setiap peserta akan diberi modul pelatihan dan diberi kesempatan untuk praktek langsung menggunakan komputer yang disediakan panitia. Adapun langkah-langkah pelaksanaan pelatihan adalah sebagai berikut :

Langkah 1 : Peserta diberi penjelasan mengenai pengertian aplikasi Microsoft Office, berbagai fasilitas yang ditawarkan aplikasi tersebut, dan penggunaan Microsoft Office secara optimal.

Langkah 2: Peserta diberi penjelasan mengenai penggunaan MS. Office Word secara umum dan bagaimana membuat surat menyurat resmi dalam administrasi desa.

Langkah 3 : Peserta yang terdiri dari perangkat desa diberi kesempatan untuk mencoba membuat format dan mengetik sendiri surat menyurat serta mengedit sendiri apa saja dokumen yang dibutuhkan dalam administrasi desa. 
Langkah 4 : Peserta diberi penjelasan mengenai penggunaan MS. Office Excel secara umum dan bagaimana membuat tabel dan perhitungan dalam administrasi warga serta untuk masyarakat yang kebanyakan adalah petani sebagai wawasan mereka untuk pendataan masa dan hasil panen.

Langkah 5 : Peserta dari warga masyarakat sendiri megikuti serta diadakan diskusi tanya jawab untuk kebutuhan masyarakat disana terutama untuk kegiatan ekonomi jual beli, mempromosikan hasil pertanian serta kebunya dan pendataan hasil panen masyarakat.

Langkah 6 : Peserta akan dikelompokkan dan diberikan tugas sesuai dengan materi yang telah disampaikan.

Langkah 7 : Seusai pelaksanaan kegiatan, seluruh peserta akan diberi sertifikat pelatihan.

\section{HASIL DAN PEMBAHASAN}

Kegiatan sosialisai dan pelatihan MS. Office Word dan Excel bagi Perangkat dan Masyarakat Desa Ciaruteun Ilir Bogor dalam rangka menumbuhkan sikap peduli lingkungan menuju Indonesia buta teknologi dan pengetahuan tentang IT khususnya dalam bidang administrasi.

Hasil dari kegiatan sosialisasi dan pelatihan MS. Office Word dan Excel di fokusnya pada tujuan awal kegiatan PKM ini antara lain sebagai berikut :

1. Melalui kegiatan sosialisasi dan pelatihan MS. Office Word dan Excel ini dapat mengetahui peran Teknologi Informasi untuk menambah pengetahuan, wawasan, dan dapat menggunakan salah satu aplikasi TI untuk mengembangkan kemampuan administrasi desa.

2. Melalui kegiatan PKM ini merupakan bentuk kerjasama dan kemitraan dengan masyarakat sebagai perwujudan dari pengembangan kompetensi social di kalangan para dosen dan sebagai perwujudatan dari tri darma perguruan tinggi.

3. Melalui kegiatan PKM ini dapat memperkenalkan profil STT PLN di masyarakat umum dan mempererat hubungan antara Civitas Akademika STT PLN dengan warga masyarakat Desa Ciaruteun Ilir Bogor.

4. Seluruh perangkat desa dan warga masyarakat Desa Ciaruteun Ilir Bogor menjadi lebih paham dan mengerti bagaimana mengolah suatu informasi dan lebih menjadi bermanfaat lagi serta dapat melakukan administrasi, surat menyurat dan lainnya dengan memanfaatkan teknologi dari MS. Office Word dan Excel. 


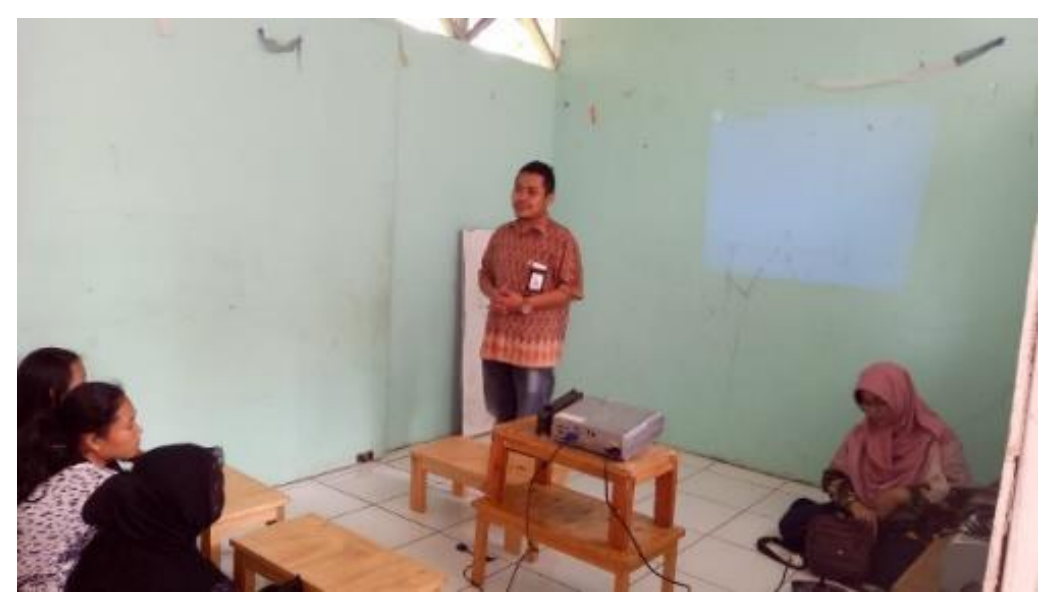

Gambar 3. Pembukaan Ketua Pelaksana

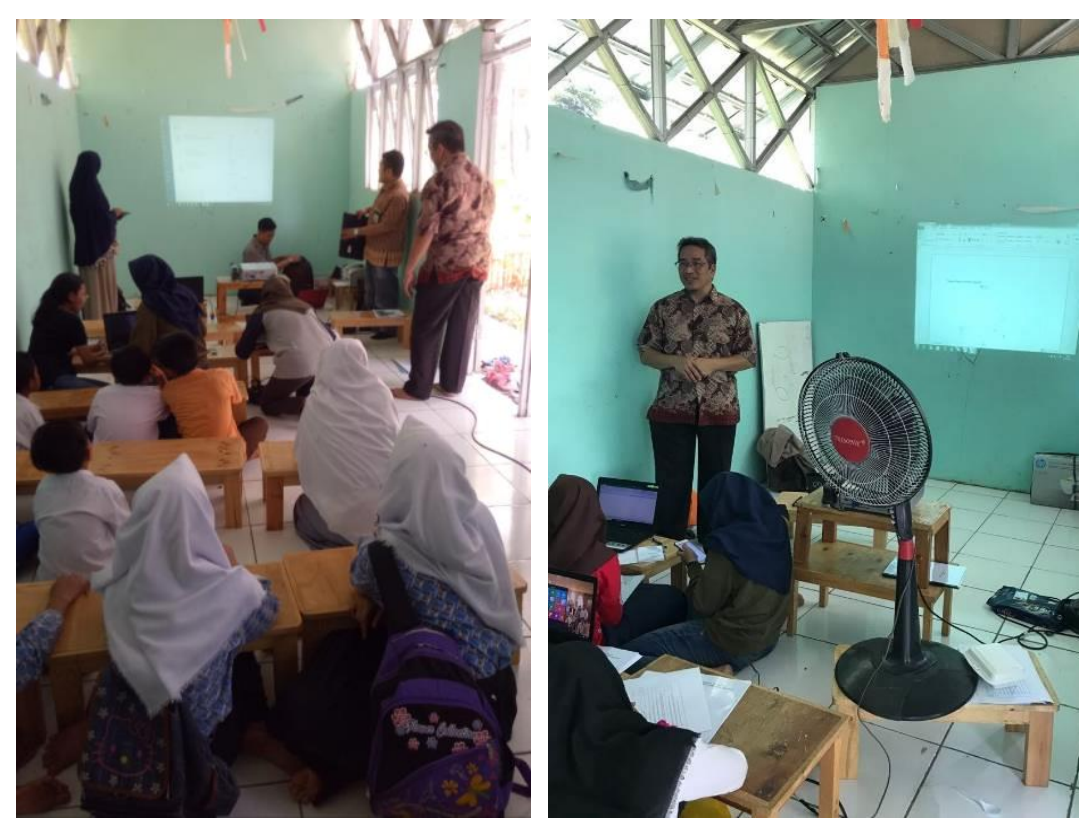

Gambar 4. Kegiatan Awal 


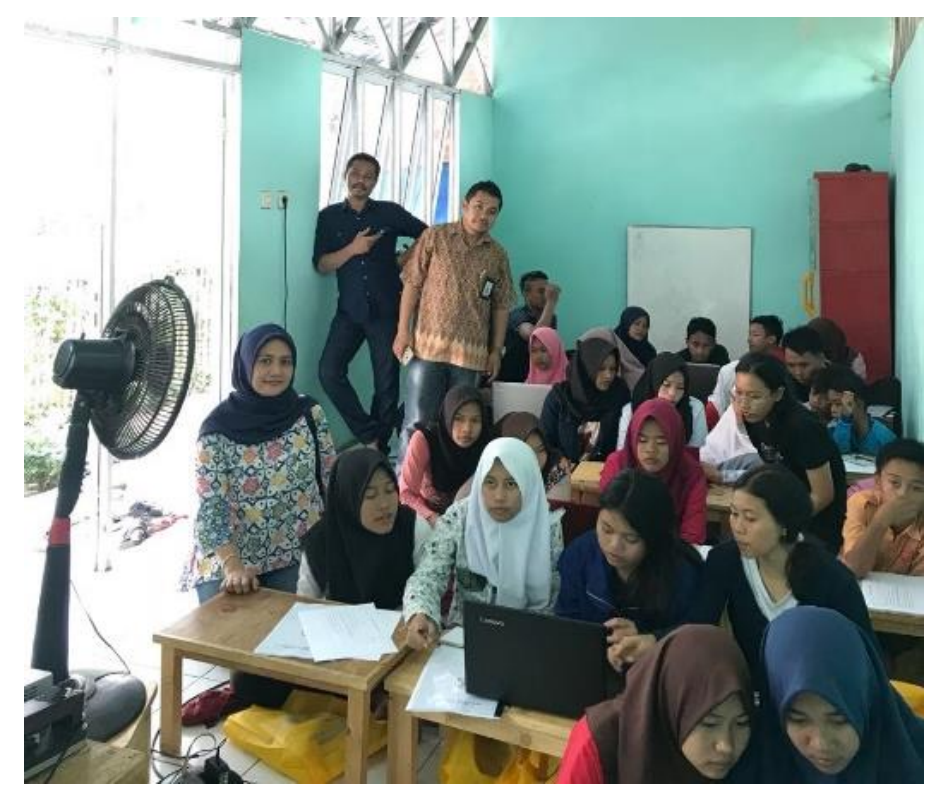

Gambar 5. Foto kegiatan berlangsung

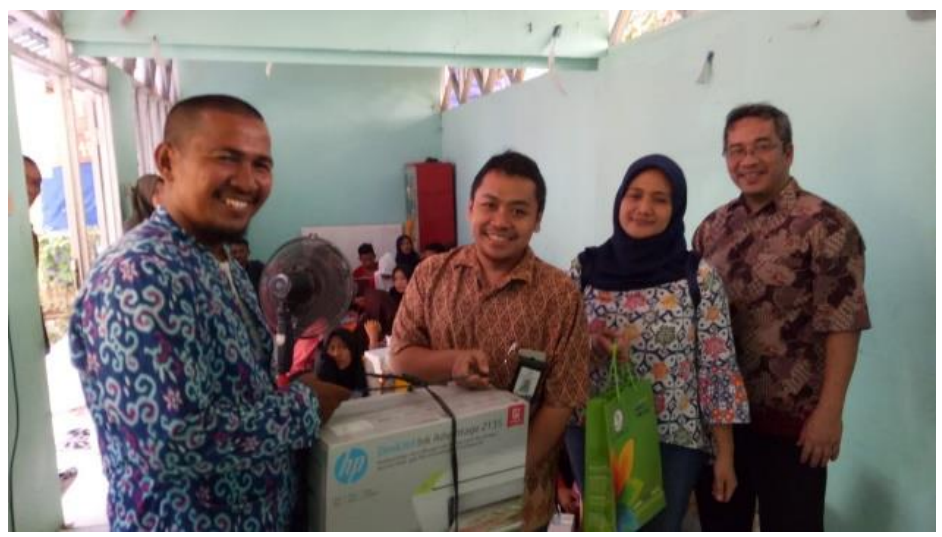

Gambar 6. Penyerahan bantuan

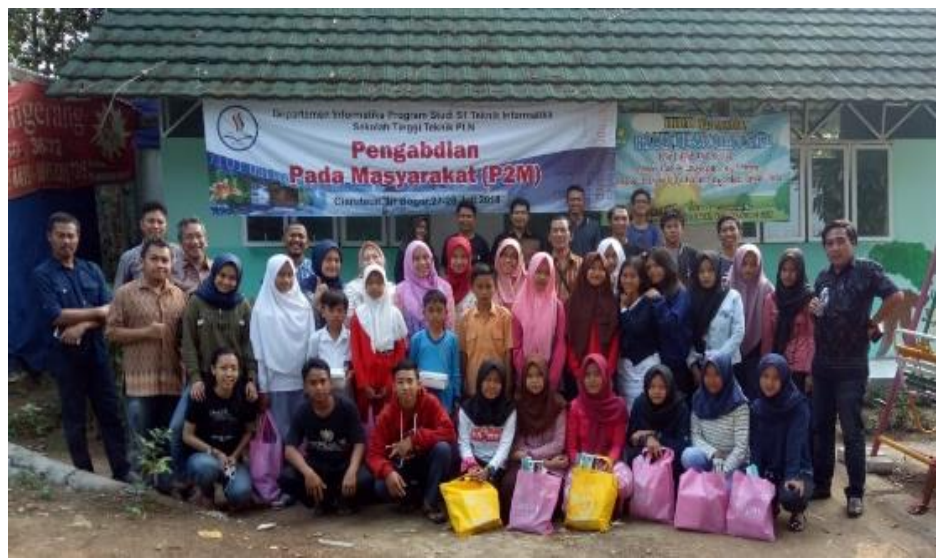

Gambar 7. Foto bersama peserta pelatihan anak -anak 
Sesuai dengan rencana target luaran, dengan dilaksanakannya kegiatan sosialisasi dan pelatihan MS. Office Word dan Excel ini diharapkan dapat membantu meningkatkan penerapan IPTEK di kalangan masyarakat umum terutama warga masyarakat Desa Ciaruteun Ilir Bogor, dimulai dari kalangan siswa SD kelas 4, 5, 6 serta siswa SMP dan SMA dengan harapan program ini akan dengan mudah tersosialisasikan dan akhirnya sampai pada khalayak umum di desa mereka dan dapat berkontribusi memajukan desaya dalam bidang IPTEK dan ICT.

\section{KESIMPULAN}

Kesimpulan yang dapat di ambil dari seluruh rangkaian acara Program Kemitraan Masyarakat dangan judul Pelatihan Ms. Office Word Dan Excel Bagi Perangkat Desa \& Masyarakat Desa Ciaruteun Ilir Bogor adalah :

1. Melalui kegiatan sosialisasi dan pelatihan MS. Office Word dan Excel ini dapat mengetahui peran Teknologi Informasi untuk menambah pengetahuan, wawasan, dan dapat menggunakan salah satu aplikasi TI untuk mengembangkan kemampuan administrasi desa.

2. Seluruh perangkat desa dan warga masyarakat Desa Ciaruteun Ilir Bogor menjadi lebih paham dan mengerti bagaimana mengolah suatu informasi dan lebih menjadi bermanfaat lagi serta dapat melakukan administrasi, surat menyurat dan lainnya dengan memanfaatkan teknologi dari MS. Office Word dan Excel.

3. Optimalisasi tujuan PKM memerlukan keseriusan serta kepedulian dari berbagai lapisan elemen masyarakat seperti tim pelaksana, institusi tim pelaksana serta pihak mitra guna meningkatkan kesejahteraan kehidupan bermasyarakat serta turut menjaga kelestarian lingkungan hidup menuju Indonesia sadar teknologi di semua pelosok desa.

4. Berdasarkan evaluasi yang dilakukan terhadap kegiatan ini menunjukkan bahwa kegiatan ini masih dapat dilanjutkan kembali mengingat adanya permintaan dari desa tersebut dari perangkat desa terutama dari warga masyarakat dalam menerima kegiatan PKM tim kami dimasa mendatang.

\section{SARAN}

Berdasarkan kendala serta uraian kegiatan diatas, saran yang dapat kami berikan anatara lain sebagai berikut :

1. Pemilihan Lokasi mitra yang jauh dari tempat institusi tim PKM menjadikan pembengkakan di alokasi dana sektor transportasi dan akomodasi sehingga dana untuk kebutuhan yang lain - lainnya perlu ada pengalokasian yang efektif dan efisien.

2. Butuh dana yang sangat besar untuk membangun sebuah desa binaan yang terpencil lokasi dan akses jalan yang sulit ini, sehingga untuk kedepannya kita 
maju untuk PKM ke desa tersebut apabila prososal untuk dana Hibah Dikti PKM lolos dan disetujui.

3. Diharapkan kedepannya dari pihak akademisi dari bidang keilmuan yang berbeda di STT PLN seperti Teknik Sipil yang akan menangani di bidang infrastruktur dan sanitasi, Teknik Elektro dan Teknik Mesin yang akan menangani di bidang Teknologi Listrik Terbarukan, penerangan dan pengairan yang lebih modern lagi.

4. Pemlihan lokasi PKM selanjutnya diharapkan benar - benar mempertimbangkan dari sisi kebutuhan dari pihak mitra, lokasi yang mudah di tempuh dan lokasi yang dekat dengan institusi tim PKM serta dana yang perlu dipertimbangkan dengan matang.

\section{UCAPAN TERIMA KASIH}

Penulis mengucapkan terima kasih kepada STT-PLN dan seluruh warga Desa Ciaruteun Ilir, Kecamatan Cibungbulang yang telah berpartisipasi serta memberi dukungan dalam pelaksanaan kegiatan pengabdian pada masyarakat.

\section{DAFTAR PUSTAKA}

1) Dix, A. et al, Human Computer Interaction $3^{\text {rd }}$ edition, Pearson Education Limited, England, 2004.

2) Ekasari, P., dan A.H. Dharmawan, Socio Economic Impacts by the Internet Usage in Villages, Sodality : Jurnal Sosiologi Pedesaan, Vol. 06, No. 01, April 2012.

3) Loudon, K.C dan Carol G.Traver, E-Commerce, Pearson, New Jersey, 2007.

4) Padmannavar, S.S., A Review on E-Commerce Empowering Women, International Journal of Computer Science and Telecommunications, Volume 2 , Issue 8, November 2011.

5) Santosa, I., Interaksi Manusia dan Komputee edisi 3, Penerbit ANDI, 2010.

6) Wiradiputra, M., Perkembangan dan Kemajuan Internet, www.academia.edu

7) kominfo.go.id 